\title{
THE MULTICRITERIA ASSESSMENT OF THE SPATIAL PLANNING PROCESS: THE ASPECT OF INVESTMENT
}

\author{
Andželika KOMAROVSKA, Leonas USTINOVICHIUS, Aurelija PECKIENE் \\ Department of Construction Technology and Management, Faculty of Civil Engineering, \\ Vilnius Gediminas Technical University, Sauletekio al. 11, LT-10223 Vilnius, Lithuania
}

Received 10 Feb 2015; accepted 15 May 2015

\begin{abstract}
The effectiveness of an investment determined by the macroeconomic situation of a country stimulates national macroeconomic development. The principles of sustainable development must be followed in order to effectively organize the spatial planning process. To ascertain the efficiency of the legal base of Lithuanian spatial planning, a comparison of the Lithuanian spatial planning organization process with those carried out in Poland and Germany has been performed. For this purpose, the basic principles of spatial planning legislation have been analyzed. The challenge was addressed to the analysis of the verbal spatial planning system. Verbal decision-making system UniComBOS (Unit Comparison for the Best Selection Object) is used for determining a model for an effective spatial planning system. The modified concept of the spatial planning model is suggested in accordance with the results obtained in the run of the carried out analysis.
\end{abstract}

Keywords: investment attractiveness, verbal decision making system, free economic zone (FEZ), investment incentives, multi-criteria decision-making, compromise solution, spatial planning.

\section{Introduction}

Legal elements are one of the most direct impact factors in the real estate market (Simanavičienè et al. 2012a, 2012b). Also, legal characteristics need to be distinguished in terms of real estate. Normative regulation is considered the basic characteristic of real estate. The physical-economic movement of real estate is controlled by regulatory acts.

The adopted laws define movement limits to real estate: allow buying, selling and privatizing it, ensuring ownership rights and approving requirements for the purchase - selling of real estate. What is more, various restrictions and the regulation of real estate transactions play a protective role (Simanavičiene et al. 2012a, 2012b). Spatial planning and the complexity and costs of the technical design process should be evaluated and integrated, since it is the expenses associated with the implementation of the investment project. The companies of construction and real estate are forced to raise the selling price of assets in order to reduce investment risk.

It is also important to note that the Spatial Planning Law (1995) was changed 25 times since 1 January 1996. On 1 May 2004, the law was substantially changed. Upon entering into force of the above mentioned version, land use change was suspended until the overall plans of municipal areas or their parts are developed. Recently, the enacted Spatial Planning Law (1995) recasting the law has been planned to a paradigm shift in spatial planning. However, the consequences of enacting this law in spatial planning and investment can be determined only after a while. It should be noted that the Construction Law (1996) has been changed 33 times since 1 September 1996. The Value Added Tax Law (2002) has been changed 49 times since 1 July 2002. All valid laws passed in Lithuania remain in the similar situation. This frequent recasting of the laws and relevant secondary legislations cause a very high level of investment risk and reduce the attractiveness of investment in the country.

A review of research works proposed that the risk of various aspects of construction projects was identified and studied by Rohaninejad and Bagherpour (2013), Abdul-Rahman et al. (2013), Wibowo and Mohamed (2010) and Zayed et al. (2008). The critical factors affecting contractors' risk attitudes in construction projects in China were investigated by Wang and Yuan (2011). Al-Azemi et al. (2014) presents an evaluation framework based on the analytical hierarchy process technique used for assessing the most common and significant decision factors relating to risks in build-operate-transfer projects. $\mathrm{Ng}$ and Loosemore (2007), Abednego and Ogunlana (2006), Ke et al. (2010, 2012), Bing et al. (2005) analyse risk distribution between public and private sectors and their

\footnotetext{
Corresponding author: Aurelija Peckienè
}

E-mail: aurelija.peckiene@vgtu.lt 
consequences. Xu et al. (2012) introduces a funded study aimed at developing a practical and computerized risk evaluation model for public-private partnership projects. El-Sayegh (2007) identifies and assesses risks in UAE construction industry and addresses their proper allocation. Lam et al. (2007) offers a decision model transforming linguistic principles and experiential expert knowledge into more usable and systematic quantitativebased analysis by using fuzzy logic. Andi (2006) identified and evaluated 27 construction risks. Hassanein and Afify (2007) found seven risk categories. Zou et al. (2007) ascertained 25 key risks in construction projects in China. Typical construction risks detect and describe a comparison between FIDIC (Federation Internationale Des Ingenieurs Conseils) and the Taiwanese government conditions for a contract concerning projects on hydropower construction (Charoenngam, Yeh 1999). Khattab et al. (2007) examine the vulnerability of international projects on political risks. N. A. Kartam and S. A. Kartam (2001) point out two types of risk management methods: preventive, which are effective at the early stages of the project life, and mitigative, which are remedial actions aimed at risk minimization during construction. Zou and Li (2010) developed a risk checklist followed by proposing a methodology for risk analysis using the fuzzy analytical hierarchy process (AHP). Adams (2008) presents an application of an expert elicitation model and Bayesian methods for analyzing the risk of payment delays in international contracts set in a developing economy, and the determination of how differing perceptions about risks affect estimates for risk. Nieto-Morote and Ruz-Vila (2011) suggest a risk assessment methodology based on the Fuzzy Set Theory that is an effective tool for dealing with subjective judgment and refer to the Analytic Hierarchy Process (AHP) applied for structuring a large number of risks.

Banaitienè et al. (2011) reports research aimed at discovering how construction companies perceive the significance of construction project risks they face and the extent to which they employ potential risk responses. Barber (2005) investigates internally generated risks. Chen et al. (2011) presents a multi-criteria decision analysis of environmental risk assessment with regard to avoiding and eliminating damage and loss under natural disasters in international airport projects. Doloi (2012) revealed that design complexity, financial structure and government policy were the three main common factors affecting risks across time, cost and operational performance in public-private partnership projects. Perminova et al. (2008) proposes a new definition of uncertainty as a crucial element in managing projects. Jun et al. (2011) reveals that project uncertainty can moderate the effects of project planning and control on process performance and the effects of user participation on product performance. Sanderson (2012) discusses different explanations for performance problems exhibited by a number of megaprojects and examines the proposed solutions to governance. Schieg (2006), Zavadskas et al. (2010), Reed and Knight (2010), Kutsch and Hall (2010) and Zhang (2007) also examined and described risk identification and management processes in various projects.

Currently, foreign investors have been quite careful while investing in Lithuania, as they cannot expect higher investment returns compared to other EU countries. Investment return in Lithuania is $8-9 \%$ of the average and is roughly equal to the inflation rate. However, commercial property return has been relatively stable and wellbalanced over the past few years. The current profit of investment transactions in the regions of Vilnius, Kaunas and Klaipeda makes $7.0 \%$ to $9.5 \%$ and is $1.0-1.5 \%$ higher compared with other major cities of Lithuania (Bank of Lithuania 2013).

The Lithuanian part of investment versus to the Gross Domestic Product (GDP) into non-residential buildings and structures is still significant at par with other EU countries; however, a drop in these expenses reduces investment in Lithuania. State-funded investments in infrastructure (Bank of Lithuania 2013) are among the most decreasing ones. Therefore, the ambition of Vilnius district regarding the development of engineering infrastructure in industrial and commercial free zones is based on boosting sustainable development and attracting investors. Investments, spatial planning and constructions are interrelated and mutually influencing processes. Therefore, for assessing investment climate for construction, it is necessary to evaluate the complexity of spatial planning documents and time for preparing them. The paper is aimed at suggesting the modified concept of the spatial planning model in order to encourage investment.

\section{Existing spatial planning system}

Spatial planning within the legal system of the Republic of Lithuania is understood as territorial spatial development prioritizing land usage, environmental and cultural heritage protection and other determined conditions for land, forest, water, residential areas, development of the industry and infrastructure system, regulation of population employment and setting individual and legal development rights of personal activity in the territory. Taking into account the range of spatial planning and the fact it is intended to ensure particular ecological, social, cultural and (or) economic importance for environmental protection areas, it turns to be clear that specific land use regimes and activities limiting the setting process in particular are closely linked to making the interests of the state, society, land and other real estate owners (managers, users) more harmonious thus protecting their rights and legitimate expectations by laws and other regulations. The implementation of spatial planning documents leverages not only the rights and legitimate interests of property owners (managers, users) in the planned area but also the economic and social development of the area, the environment and its individual elements, the health of society members, cultural heritage and other objects 
important to the state and society. The confirmed document of territorial planning expresses not only the state (local authorities) policy of a particular area but also a compromise between the state (municipality) and its representative bodies, property owners and society and its individual members. Therefore, only compliance with laws and provisions of legal acts (not in conflict with a higher-ranking law) during the spatial planning process is an assumption about harmonizing and ensuring the state, society, natural and legal rights and legitimate interests.

General planning, which is one of spatial planning types, can be defined as the complex planning of the spatial development policy to set land use, security priorities and key management measures (Spatial Planning Law 1995, Section 2.2). Territory planning is a difficult, timeconsuming complex planning process during which the needs of society, planned landscape features, geographical location, geological conditions, urban, architectural, engineering and environmental heritage, agricultural land use and management requirements, land and other real estate owners and third-party rights, national security and defence needs are coordinated. General planning though, should be made «easier and more sustainable" and more flexible since it is the basis for lower-level plans, which means its preparation procedure should be simplified but by all means not simplifying its solutions. However, on the contrary - it should become a more informative, understandable strategic planning document required for the land owners of the planned territory, and, at the same time - adapting to the changing environment and balancing sustainable development needs of participants.

In accordance with Article 2 Paragraph 3 of the Spatial Planning Law (1995), the detailed plan is perceived as a spatial planning document that sets plot limits, land management and utilization mode (mandatory conditions for constructions and other activities). Procedures approving a detailed plan (used setting the legal status of the territory) are a part of the legal facts of the composition necessary for certain relationships to occur, and its characteristic feature is the fact for other legislation to be adopted based on the detailed plan following which it can be is approved. Detailed plans do not reflect the abstract general rule of the law (code of conduct), primarily because they do not directly express general instructions on acting accordingly. These plans establish the legal status of a certain territory that is not directed towards the unspecified group of the entities of individual features but is related with the setting certain conditions for activities carried out in the territory. These issues, in more detail, have been examined and described by Šostak and Makutenienè (2013a, 2013b). The entire detailed plan (or its individual components) is always associated with a specific, clearly in terms of space, identifiable plot (area) rather than with the group of entities specified by individual attributes. The legal status of the territory assessed by the detailed plan is formed of the parts associated with specific plots.
The interface of construction investment and spatial planning processes, in accordance with the current legislation, is shown in Figure 1. The optimistic performance term of 1.5 years is determined by the analysis of spatial planning procedures and arranging them in time. If an investment project containing right information could be developed fairly quickly, the risk might arise during the assessment of the number of detailed planning procedures and the time frame that is difficult to measure and define. During this period, a sudden drop in prices is possible, which ruins the whole investment project. Currently, spatial planning procedures are complex, long and risky. Thus, in conclusion, the incompleteness of general plans and preparation time for the detailed plan are the major threats concerning projects on investment in the region.

It is obvious that the current spatial planning regulation involves more planning process and a description of procedures and does not guarantee the quality of spatial planning documents, does not eliminate errors and allows irrational land use. Under statutory deadlines, the preparation of the detailed plan takes about 150 work days, i.e., 30 weeks regardless the time required for preparing a solution to the plan. Taking into account procedures for preparing a relevant planning document, it takes about 350 work days, i.e. 70 weeks. Considering the above, the following conclusions are appropriate:

- the current legal regulation of spatial planning is confusing and complicated;

- the current Spatial Planning Law (1995) provides the necessity for preparing too many spatial planning documents;

- undefined key task for the sustainable development of spatial planning is to indicate the elements of public interest in the areas - public infrastructure, natural and cultural heritage, natural resources guarantying the essential requirements for the quality of life;

- the detailed spatial planning of a single plot becomes a private validation tool for economic activity;

- spatial planning documents do not lead to rational land use maintaining a rational balance of the urbanized and non-urbanized area;

- no effective mechanism for control over changes in the main land use has been established.

The content and procedures of territorial planning documents of environmental impact assessment (EIA), strategic environmental impact assessment (SEIA) and public health impact assessment (PHIA) are formal and duplicate each other. This is the reason why spatial planning documents do not ensure environmentally-friendly solutions, and their preparation takes an unpredictable amount of time and requires additional resources (Komarovska 2013). 


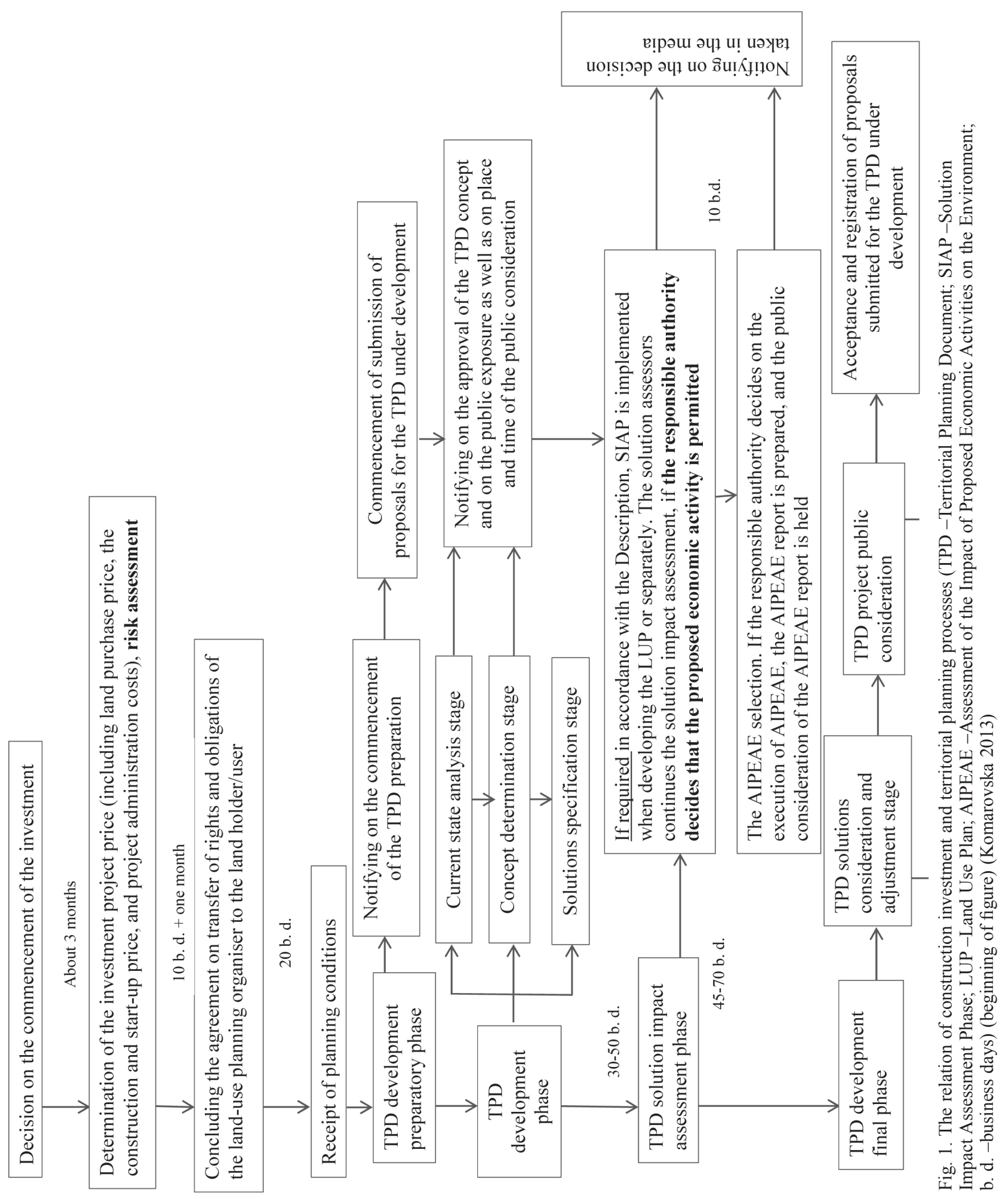




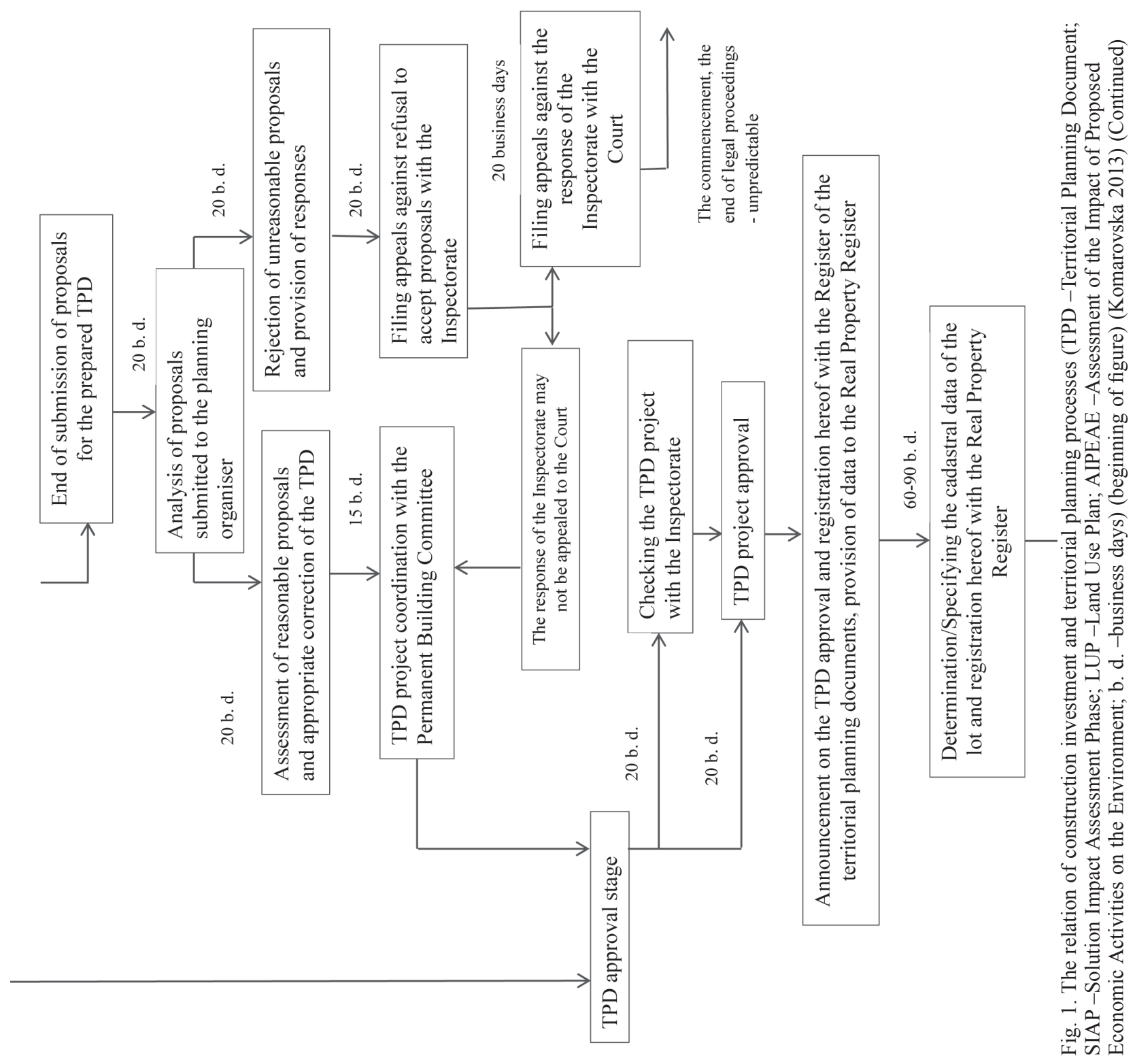



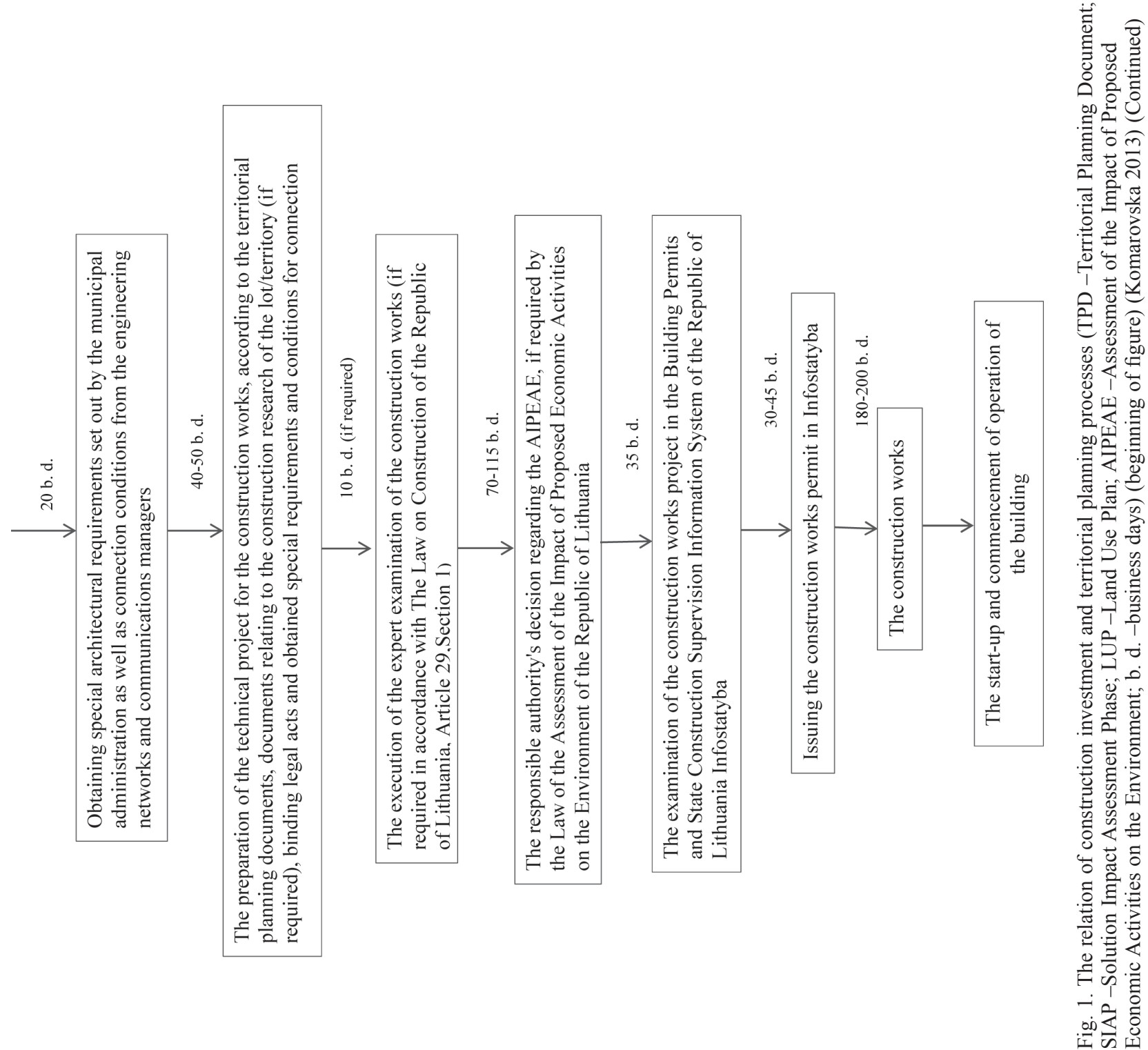
Table 1. Detailed planning and the main features (current situation) (Komarovska 2013)

\begin{tabular}{|c|c|c|c|}
\hline Country & Germany & Lithuania & Poland \\
\hline $\begin{array}{l}\text { Name in } \\
\text { the national } \\
\text { language }\end{array}$ & Bebauungsplanung & Detalusis planavimas & $\begin{array}{l}\text { Miejscowy plan zagospodorovania } \\
\text { Przestrzennego (MPZP) }\end{array}$ \\
\hline Planning object & $\begin{array}{l}\text { The area of the } \\
\text { municipality }\end{array}$ & $\begin{array}{l}\text { Land plots or a group of plots, urban } \\
\text { areas, towns or their parts, country } \\
\text { areas }\end{array}$ & $\begin{array}{l}\text { Neighbourhood } \\
\text { (community) area or the parts of it }\end{array}$ \\
\hline $\begin{array}{l}\text { Binding to } \\
\text { prepare }\end{array}$ & $\begin{array}{l}\text { As soon as possible and } \\
\text { in accordance with the } \\
\text { elements needed for urban } \\
\text { development }\end{array}$ & $\begin{array}{l}\text { Required as a basis for construction, } \\
\text { land use, resources and buildings, } \\
\text { taking land for public needs }\end{array}$ & $\begin{array}{l}\text { Optional but desirable as a basis for } \\
\text { land planning and issuing permits }\end{array}$ \\
\hline Main goals & $\begin{array}{l}\text { Legally restricting } \\
\text { urban development } \\
\text { (including building } \\
\text { rights), forms the base } \\
\text { for the implementation of } \\
\text { measures in the future }\end{array}$ & $\begin{array}{l}\text { Establish and legalize conditions } \\
\text { for spatial development taking into } \\
\text { account a geographical situation, } \\
\text { requirements for protecting urban, } \\
\text { natural and cultural heritage and the } \\
\text { interests of third parties }\end{array}$ & $\begin{array}{l}\text { Detailed land use; } \\
\text { construction standards and conditions; } \\
\text { principles of the spatial division into } \\
\text { construction sites }\end{array}$ \\
\hline Publicity & $\begin{array}{l}\text { Municipality (city hall), } \\
1 \text { month }\end{array}$ & $\begin{array}{l}\text { Local media, } 20 \text { business days } \\
\text { of access, } 10 \text { of which for public } \\
\text { exposure }\end{array}$ & $\begin{array}{l}\text { Exposure in neighbourhoods } \\
\text { (communities) and for } 3 \text { weeks in the } \\
\text { office is strictly required by law }\end{array}$ \\
\hline $\begin{array}{l}\text { Necessary } \\
\text { conditions } \\
\text { for approval / } \\
\text { expertise }\end{array}$ & $\begin{array}{l}\text { In special cases, under the } \\
\text { approval of higher-level } \\
\text { executives }\end{array}$ & $\begin{array}{l}\text { Under the approval of State } \\
\text { Territorial Planning and Construction } \\
\text { Inspectorate under the Ministry of } \\
\text { Environment }\end{array}$ & $\begin{array}{l}\text { Provincial development plans, state } \\
\text { policies and principles must be } \\
\text { taken into account; no requirement } \\
\text { for the approval of higher authority, } \\
\text { compliance with legal regulations is } \\
\text { checked only }\end{array}$ \\
\hline Approval by & The Municipal Council & The Municipal Council & $\begin{array}{l}\text { Community Board and/or } \\
\text { Administration }\end{array}$ \\
\hline $\begin{array}{l}\text { Coordinated } \\
\text { with }\end{array}$ & $\begin{array}{l}\text { Government institutions, } \\
\text { neighbouring } \\
\text { municipalities, } \\
\text { community }\end{array}$ & $\begin{array}{l}\text { Conditions issuing authorities; } \\
\text { community }\end{array}$ & $\begin{array}{l}\text { Voivode (regional representative of } \\
\text { the central government); regional } \\
\text { (sub) Board; neighbouring municipal } \\
\text { management; regional representatives } \\
\text { of the sectoral administrations named } \\
\text { by the law }\end{array}$ \\
\hline Legal affects & $\begin{array}{l}\text { Legally restricting all; } \\
\text { a legal basis for the } \\
\text { construction of projects } \\
\text { and permits }\end{array}$ & $\begin{array}{l}\text { Legally restricting; } \\
\text { forms the basis for construction } \\
\text { projects and permits; } \\
\text { imposes restrictions on urban and } \\
\text { rural areas }\end{array}$ & $\begin{array}{l}\text { Restricting local authorities and third } \\
\text { parties; form the basis for decisions } \\
\text { regarding conditions for construction } \\
\text { and land use (planning permission) }\end{array}$ \\
\hline $\begin{array}{l}\text { Compensation } \\
\text { for damage } \\
\text { suffered by } \\
\text { planning } \\
\text { restrictions }\end{array}$ & $\begin{array}{l}\text { Mainly banning or } \\
\text { changing permitted use by } \\
\text { some other special permits }\end{array}$ & $\begin{array}{l}\text { Property owner or operator may apply } \\
\text { if the plan takes effect; not possible } \\
\text { under the previous method, or the } \\
\text { former intended use of property }\end{array}$ & $\begin{array}{l}\text { The impairment of assets, and the } \\
\text { owner wants to sell it }\end{array}$ \\
\hline $\begin{array}{l}\text { Report on } \\
\text { implementation }\end{array}$ & None & $\begin{array}{l}\text { If a program defined development, } \\
\text { the program or activity is proposed } \\
\text { to change }\end{array}$ & In four cases, strictly defined by law \\
\hline Customer & Municipality & $\begin{array}{l}\text { Landowners; land and public } \\
\text { land users; Director of Municipal } \\
\text { Administration }\end{array}$ & $\begin{array}{l}\text { The Municipal Board, the Board } \\
\text { Council, designer having an } \\
\text { authorized license }\end{array}$ \\
\hline $\begin{array}{l}\text { Changes in the } \\
\text { plan }\end{array}$ & $\begin{array}{l}\text { A simplified procedure } \\
\text { for modifications that do } \\
\text { not affect the fundamental } \\
\text { principles of the plan, in } \\
\text { all other cases - a new } \\
\text { plan }\end{array}$ & New plan & New plan \\
\hline
\end{tabular}




\section{Comparative verbal analysis regarding the assessment of general and detailed plans of the European Union Member States}

Spatial planning is one of the most important influencing factors in the implementation of national political, strategic, economic and social objectives that can be seen as holistic and combining planning (Bass et al. 1995). General spatial plans of the municipality take about 1.53 years and special plans - about 1-3 years. Transition from general plans, in case they have been developed on a large scale, to detailed plans normally held on the scale of M1:500 is very difficult and complex, in terms of the unimproved areas of engineering in particular.

The Lithuanian spatial planning process was compared with those carried out in Poland and Germany in order to determine the legal framework for Lithuanian spatial planning. The main features of the detailed planning of the current situation in Lithuania, Poland and Germany are presented in Table 1.

The task comparing models for the spatial planning system is assigned to the class of unstructured problems having qualitative variables. Since the main characteristics of such problems are qualitative, they can hardly be used for conducting analysis. On the other hand, quantitative models are not sufficiently reliable. Unstructured problems have common features. Considered along with the earlier analyzed cases, they are unique decisionmaking problems, i.e. a decision-maker always faces the unknown problem when new features appear. Alternative assessment problems are often related to the lack of information on decision-making under uncertainty. The evaluation of alternatives is qualitative as it is usually expressed verbally. Experts frequently cannot quantitatively measure qualitative variables (Ustinovichius 2004, 2007). When uncertainty is high, experts can compare the quality of alternatives based on certain criteria.

These aspects are typical of verbal decision-making methods (Korhonen et al. 1997; Larichev 1992; Furems, Gnedenko 1992; Larichev, Moshkovich 1996, 1997):

- quantitative measurements allow an adequate description of unstructured problems;

- the formulation of the rule on the final decisionmaking, according to the methods of processing human data, allows explaining the principles psychologically;

- the procedures used for performing analysis ensure the reliability of the received information allowing the DM (decision-maker) to state the final rules.

The applied method allows sorting alternatives according to the preferences of the DM. The efficiency of options is based on qualitative parameters and developed in accordance with the logical scheme for comparable alternatives. The evaluation of criteria is carried out according to the estimates expressed verbally and in relation to the scales of statements. The survey is carried out sorting out the preferences of the DM and eliminating the dependence of criteria. Some specific procedures al- low detecting and removing the dependency of indicators, and therefore the obtained information is used more efficiently. The task is solved analyzing verbal spatial planning systems UniComBOS (Unit Comparison for the Best Selection Object) (Ashikhmin et al. 2003; Ustinovichius et al. 2011). Other verbal decision methods have also been examined by Wei and Zhao (2014), Jin et al. (2013), Zhang (2013).

Structuring the problem. At the stage of structuring, the decision-making person (DM) should state the problem of selecting an alternative in a natural language in terms of the respective area of the problem. The alternatives available for selection should be listed, evaluation criteria should be determined and the verbal scales of evaluation based on each criterion should be defined. A set of alternatives for selecting the best one will be denoted by A.

The DM determines the characteristics of the alternatives to be used as evaluation criteria. Let us denote a set of criteria $C=\left\{C^{1}, \ldots, C^{k}\right\}, K=\{1, \ldots k\}$ as a set of the numbers of criteria. The criteria may be both quantitative and qualitative (verbal). Estimate alternative â̂A based on criterion $C^{j}$ will be denoted by $C^{j}$ (a). The scale of evaluation $S^{j}=\left\{s_{1}^{j}, s_{2}^{j}, \ldots, s_{m_{j}}^{j},\right\}, j \in K$ associated with a particular criterion is not specified beforehand but formed based on the estimates of all actual alternatives according to particular criterion $S^{j}=\bigcup_{a \in A} C^{j}(a)$. In this approach, the preliminary arrangement of the estimates on criterion scales is not required. Various combinations of the estimates make k-dimensional space, which, in fact, is the Cartesian product of criterion scales $S=\prod_{j=1}^{k} S^{j}$. Each alternative $\mathrm{a} \in \mathrm{A}$ corresponds to vector estimate (tuple) $\mathrm{C}(a)=\left(\mathrm{C}^{1}(a)\right.$, $\mathrm{C}^{2}(a), \ldots, \mathrm{C}^{k}(a)$ consisting of alternative estimates $C^{j}(a)$ based on criteria $C^{1}, \ldots, C^{k}$. Let us denote by $\mathrm{A}$ a set $\{\mathrm{C}(a) \mid a \in \mathrm{A}\}$ of vector estimates of real alternatives from set $A$. It is evident that $A \subseteq S$.

Thus, at this stage of problem structuring, the sets of alternatives $A$ and criteria $C$ as well as the scales of criteria $S^{j}$ and vector estimates $A$ are determined. The task is to obtain a subset of the best alternatives based on the preferences of the DM.

Formalizing the preferences of the DM. Let us introduce the additional space of vector estimates required for developing procedures for eliciting the preferences of the DM at a later stage. Let us also extend the scale of each criterion $S^{j}$ by introducing fictitious estimate $\omega^{j}$ : $Q^{j}=S^{j} \cup\left\{\omega^{j}\right\}$. Then, a set of the estimates of various vectors, including the fictitious ones, may be described by the Cartesian product of the scales of new criterion $Q=\prod_{j \in K} Q^{j}$ similar to set $S=\prod_{j \in K} Q^{j}$.

Let us consider a particular estimate of vector $x \in Q$ and a subset of the numbers of criteria $J \in K$. Let us de- 
note by $x j$ an estimate of the vector the $j$-th component of which is equal to the $j$-th component of the estimate of vector $x$ if $j \in J$, and is equal to $\omega^{j}$ if $j \in K \backslash J$. The estimate of vectors all but one values of which are fictitious will be referred to as one-criterion estimate. If two estimates are real, the estimate of the vector will be referred to as a two-criterion estimate, etc.

A description of the preferences of the DM is based on binary relations $P$ and $I$ defined on the set of vector estimates $Q$ :

- $(x, y) \in P$ if $x$ is more preferable than $y$;

- $(x, y) \in I$ if $x$ and $y$ are equally preferable;

- and the resulting binary relation is $R=P \cup I$.

In this case, for any pair of vector estimates $(x, y)$ making binary relation $P$ or $I$, the statement is valid if one of the $j$-th components is equal to fictitious estimate $\omega^{j}$; then, the $j$-th component of the other estimate of the vector is also equal to $\omega^{j}$. It is believed that binary relations $P, I$ and $Q$ have the following properties:

- $P$ is rigorous partial order (irreflexively and transitively);

- $I$ is equivalence (reflexively, symmetrically and transitively);

$-R$ is quasiorder (transitively, reflexively).

$$
P=\cap I \varnothing ; R=P \cup I \text {. }
$$

In addition to the above properties, it is assumed that the displayed criteria are inter-independent regarding preference.

Eliciting preferences from decision-makers starts with a comparison of the estimates of one-criterion vector. In this particular case, the estimates of the efficiency of the territory planning model in the considered countries and the estimates of the alternatives based on particular criteria should be elicited from the experts in the considered area. The DM makes a pairwise comparison of the estimates on the scale of each criterion. As a result, the estimates based on each particular criterion are arranged in the order of DM preferences.

Unlike other methods where the order on the criterion scale is predefined at the stage of structuring, in the case of using the UniComBOS method, criterion scales are arranged when the estimates of one-criterion vector are compared. If the scale of some particular $j$-th criterion has $m_{j}$ estimates, $m_{j}\left(m_{j}-1\right) / 2$, comparisons will be made with respect to this criterion.

Then, a pairwise comparison of vector estimates of two-, three- (and more) criteria is made. The number of criteria with real estimates is increased only if the problem cannot be solved with the given number of criteria. A special optimization procedure is used for searching a pair of vector estimates that will be presented to the $\mathrm{DM}$, which is based on the prediction model allowing judgments given by the DM in the process of comparing vector estimates to be predicted. The above optimization procedure used at this stage of eliciting DM preferences yields the pairs of vector estimates and the order of their comparison by a decision-making person.

DM preferences elicited in every operation of the pairwise comparison of vector estimates (including onecriterion estimates) are checked for agreement (consistency), and an attempt is made to determine a subset of the best alternatives. If the inconsistency of estimates is observed, its cause is determined and eliminated. This is made by showing the DM his/her previous estimates and their logical consequences. The DM may indicate a wrong answer or disagree with some intermediate result. In the first case, the DM corrects his/her estimate. In the second case, the hypothesis about the independence of the criteria of preference and/or transitivity may be violated. The basic characteristics of the systems include:

- questions about multiple criteria are not submitted until all comparability of $a$ and $b$ vectors and the problem of a smaller scale are presented;

- following each answer of the DM, compatibility check is carried out. Objections are eliminated addressing an additional question to the DM;

- questions are selected to identify the best alternatives in the subset as soon as possible (minimum number of questions) and avoiding a comparison of alternatives that are not in the selected subset.

To reduce the amount of questions submitted to the DM setting priorities according to the model forecasting those priorities. As for this model based on assessing a comparative vector of the DM, the forecasting function that "interpolates" and shows DM priorities concerning the assessment of vectors is made. The DM does not compare priorities directly and allows forecasting a comparison of responses. This information is provided by the DM choosing the pairs of vectors that are selected for their comparison to help with the evaluation of the viable alternatives to the values of vectors.

A practical alternative comparison of this paragraph is carried out as follows: the assessment of each criterion is given and their combinations are formed. An expert assigns the corresponding response to the combination of the estimates. The database of the response is stated. The algorithm for the program allows selecting four possible response options:

- first alternative is more valuable than the other;

- both alternatives are equally important;

- first alternative is less valuable than the other;

- I do not know.

The program selects alternative assessment based on two or three criteria and forms their combinations by selecting a significant response. The program provides an interim response table and a colour comparison of alternative assessment (green colour marks more, blue - less valuable results) after the DM performs an operation (Ustinovichius et al. 2011).

The program provides the table of the results based upon the answers to all the questions of the program thus choosing the best option. The performed analysis 
has showed that general spatial planning in Lithuania is organized in a more complex way compared to German and Polish planning processes. A comparison of data on UniComBos in Table 1 using the program has disclosed that not only the principles of general planning but also those of detailed planning are insufficiently favourable in Lithuania. The program explains the basis for the criteria considering the made decision. An explanation fragment of the program is given describing in detail the stages of verbal analysis, depicting a block-diagram of the procedure for eliciting DM preferences and representing a flow diagram of DM survey in the previous works of the authors (Ustinovichius et al. 2011). Hence, it is necessary to carry out the legislation analysis of spatial planning in order to exactly determine the factors/criteria to be adjusted.

\section{Analysis of the spatial planning legislation process}

Traditionally, the purpose of planning, and the planning law in particular, is to validate the role in the law enabling a public interest and promoting the welfare of society (Faludi 1973; Moore 1978; Campbell, Marshall 2002). Bearing in mind the main objective, land use plans are traditional regulatory tools (planning systems that control the areas of land zoning plans) aiming to obtain official and municipal planning policies and to specify the rights of land owners and interested parties (Alfasi et al. 2012). Land use plans meet special and detailed spatial planning documents of Lithuania.

Sustainable development is a complex multi-dimensional mechanism covering all aspects of life and gives the opportunity to solve complex problems. Spatial planning is one of the most effective ways of implementing sustainable development. The developed countries such as Germany consider planning to be the main instrument for establishing control over the country. Development directions and their enforcement of consistency describing the compatibility of plans and programs are the most important in this process. Plans and programs should be promptly carried out and constantly monitored (monitoring). Although land use plans (equivalent to the set detailed plans in Lithuania for neighbourhoods (their parts), cities, towns, villages (their parts)) are important for a number of European countries, their actual implementation usually remains undiagnosed (Alfasi et al. 2012).

The Investment Promotion Program (2008) for 2008-2013 was approved by resolution No. 2007-1219.1447 The Investment Promotion Program for 20082013 issued by the Government of the Republic of Lithuania. The program is aimed at improving Lithuania's investment environment and at creating an effective system for promoting direct domestic and foreign investment focusing on long-term national economic development, economic growth and public welfare in particular.

Long and difficult procedures (because of non-compliance with statutory time limits, land acquisition as well as due to the preparation and coordination of spatial planning documents) are included in the program containing factors limiting investment in Lithuanian economy. One of the objectives of the program is to speed up management processes of spatial planning and construction documents. It should be noted that even in accordance with the set terms, the procedures for preparing spatial planning documents are too long, often redundant or overlapping. Therefore, the realization of the investment project takes risky terms. State-funded investments in infrastructure are among the most decreasing investments. Spatial development is inseparable from infrastructure development the level of which reflects the stage of spatial coherence simultaneously creating assumptions for attracting investors. Therefore, the legislative analysis of infrastructure development in relation to residential areas will be carried out.

An important point is that the task of investment promotion in legislation on Lithuanian territory planning is not clearly defined and described by the specified criteria; they are not enshrined in law to promote investments. The author's suggestions for improving the legal framework are set in Table 2.

\section{Conceptual model for spatial planning}

In order to reduce time for preparing documents on spatial planning by simplifying procedures, public needs, the investment environment, the planned area of landscape features and its potential, geographical location, geological conditions, urban design, architecture, technical, environmental, heritage and other characteristics, national security and defence needs must be assessed in each city or district.

Each municipality is unique, and therefore the aim of the Ministry of Environment is to introduce global (centralized) spatial planning norms contrary to the principles of sustainable development. For these reasons, this paper proposes allowing each municipality to develop planning standards taking into account the peculiarities of each municipality and development objectives. The Ministry of Environment is allowed working out the methodology as regards the norms of spatial planning.

The aim of the process centralizing territorial planning remains unjustified. The strategy for priority development in each municipality depends only on the areaspecific features such as public demands, geographical location, historical-cultural traditions, transport infrastructure (railways, state roads, airports and harbours), minerals, recreation, forest potential, social phenomena, etc. and aspirations. That is why only the local administration can plan assessing the obligations and potential of their territory. It is also proposed to give up on planning conditions for preparing a new conceptual model for spatial planning. According to the established practice, requirements for the legislation are cited in the created conditions. Planning conditions cannot conflict with requirements for such legislation. That is why the conclu- 
Table 2. Constraints on infrastructure development in residential areas and propositions for their removal (Komarovska 2013)

\begin{tabular}{|c|c|c|}
\hline Nr. & $\begin{array}{l}\text { Main constrains on the development of the } \\
\text { infrastructure of residential } \\
\text { areas }\end{array}$ & Proposals for improvement in legal regulation \\
\hline 1. & $\begin{array}{l}\text { State-level general plans are accepted } \\
\text { regardless of the factors and processes } \\
\text { that may affect the implementation of the } \\
\text { objectives of the plan; they are difficult to } \\
\text { follow and change; it is difficult to carry out } \\
\text { the monitoring of implementing solutions }\end{array}$ & $\begin{array}{l}\text { Proposed to the Seimas to develop national development strategies, } \\
\text { coordinate and monitor their implementation on the level of regions and } \\
\text { districts, set the policies of national sustainable development, develop } \\
\text { spatial planning legislations and special plans of national importance, etc. }\end{array}$ \\
\hline 2. & $\begin{array}{l}\text { The law on the spatial planning of the } \\
\text { Republic of Lithuania creates opportunities } \\
\text { to develop detailed plans for an individual } \\
\text { land plot under general plan solutions by } \\
\text { transferring land owners only and planning } \\
\text { organizer rights and obligations regardless } \\
\text { of the potential for providing necessary } \\
\text { engineering infrastructure in the areas. }\end{array}$ & $\begin{array}{l}\text { Create mechanisms for stopping the chaotic dot development of spatial } \\
\text { planning in the legal system. Suggestions: } \\
\text { 1. to leave spatial planning rights for the administrative director, with the } \\
\text { exception of the case described on page 3; } \\
\text { 2. to improve areas under the development plan only depending on } \\
\text { strategic documents prepared by the municipality; } \\
\text { 3. to transfer the rights and obligations of the organizer of individual } \\
\text { blocks planned to be urbanized under the general plan to the private } \\
\text { investor and to provide him with the rights and obligations of } \\
\text { implementing solutions in accordance with the detailed plan related } \\
\text { signing the agreement of co-operation with the Administrative Director } \\
\text { incurring specific financial obligations }\end{array}$ \\
\hline 3. & $\begin{array}{l}\text { The law of the Republic of Lithuania does } \\
\text { not integrally regulate residential areas of } \\
\text { infrastructure development }\end{array}$ & $\begin{array}{l}\text { The specificity of developing infrastructure in residential areas requires } \\
\text { development to be carried out in accordance with development priorities } \\
\text { approved by municipalities and considering the development costs of } \\
\text { infrastructure }\end{array}$ \\
\hline 4. & $\begin{array}{l}\text { Regulations on developing the same } \\
\text { detailed plans are set for the areas already } \\
\text { equipped with public utilities, transportation, } \\
\text { communication and social infrastructure and } \\
\text { for the places where these infrastructures } \\
\text { have not been developed }\end{array}$ & $\begin{array}{l}\text { A suggestion is to separate the regulatory principle of developing the } \\
\text { infrastructure of residential areas and the rights and obligations of the } \\
\text { participants of this process in view of different conditions between urban } \\
\text { areas with public utilities, the shared use of traffic communications and } \\
\text { expected to be urbanized areas where these infrastructures have not been } \\
\text { developed }\end{array}$ \\
\hline 5. & $\begin{array}{l}\text { The development of infrastructure in } \\
\text { residential areas is not considered of a public } \\
\text { interest and becomes the duty of a private } \\
\text { individual entity (builders) implementing } \\
\text { investment projects }\end{array}$ & $\begin{array}{l}\text { A suggestion is to identify the development of infrastructure in residential } \\
\text { areas of a public interest and to provide respective rights and duties for } \\
\text { the participants of related development (municipalities, utility services, } \\
\text { land owners and land users). } \\
\text { A suggestion is to define the boundaries of urbanized areas regarding } \\
\text { general plans and solutions to infrastructure development concerning the } \\
\text { main residential areas and their implementation }\end{array}$ \\
\hline 6. & $\begin{array}{l}\text { The development of specific plans does } \\
\text { not solve the complex of the problems of } \\
\text { infrastructure development in residential } \\
\text { areas }\end{array}$ & $\begin{array}{l}\text { A suggestion is to renounce special plans as a separate type of a planning } \\
\text { document, whereas solutions are duplicated (especially when plans are } \\
\text { prepared at the same scale) }\end{array}$ \\
\hline 7. & $\begin{array}{l}\text { Land use schemes and plans are considered } \\
\text { as territorial planning documents }\end{array}$ & $\begin{array}{l}\text { A suggestion is related to spatial planning to be carried out by the } \\
\text { planning standards approved by the Municipal Council and development } \\
\text { solutions to the required detailed plans of the infrastructure of residential } \\
\text { areas }\end{array}$ \\
\hline 8. & $\begin{array}{l}\text { Lack of closely regulated connection to } \\
\text { utility networks in urban areas belonging to } \\
\text { the public water supplier or a private person } \\
\text { (engineering network owners and users, etc.). }\end{array}$ & $\begin{array}{l}\text { A suggestion is to apply the following provision for connection to public } \\
\text { utilities and communications in urban areas: } \\
\text { The Government or its authorized institution shall adopt standard terms } \\
\text { of the contract for the builder (new user) to connect to public utilities } \\
\text { and communications belonging to the public water supplier or private } \\
\text { individuals }\end{array}$ \\
\hline
\end{tabular}

sion about the redundant procedure can be made. The preparation of detailed plans must be performed in accordance with requirements for legislation and planning norms.

The concept of the new version of the Law on Territorial Planning approved by resolution No. 422 (The concept... 2010), issued by the Government of the Republic of Lithuania in the summary of the foreign planning practices submits traditions, national planning policy and the current legal framework for spatial planning findings. However, the preparation of amendments to the Spatial Planning Law came into effect on 1 January 2014 and was not based on the above introduced findings. According to changes in the process of suggested spatial planning given in Table 2, a new conceptual model for spatial planning is being developed. According to the model for 
Table 3. Detailed planning procedures at the municipal level in the countries concerned (in accordance with the new conceptual model) (Komarovska 2013)

\begin{tabular}{|c|c|c|c|}
\hline Country & Germany & Lithuania & Poland \\
\hline $\begin{array}{l}\text { Binding to } \\
\text { prepare }\end{array}$ & $\begin{array}{l}\text { Mandatory. As soon as possible } \\
\text { and in accordance with the } \\
\text { elements needed for urban } \\
\text { development }\end{array}$ & $\begin{array}{l}\text { Mandatory in urban areas and by } \\
\text { the need for development }\end{array}$ & Mandatory \\
\hline Publicity & 1 month & $\begin{array}{l}20 \text { business days, } 10 \text { of which for } \\
\text { public exposition }\end{array}$ & $\begin{array}{l}\text { Exposition at the community } \\
\text { (neighbourhood) office for } 3 \\
\text { weeks }\end{array}$ \\
\hline $\begin{array}{l}\text { Planning } \\
\text { objectives }\end{array}$ & $\begin{array}{l}\text { Legally restricting urban } \\
\text { development (including building } \\
\text { rights); forms the basis for the } \\
\text { implementation of measures in } \\
\text { the future }\end{array}$ & $\begin{array}{l}\text { Defines and establishes conditions } \\
\text { for area development taking into } \\
\text { account the growth of engineering } \\
\text { infrastructure and perspectives for } \\
\text { social needs }\end{array}$ & $\begin{array}{l}\text { Detailed land use; } \\
\text { local standards and construction } \\
\text { conditions; } \\
\text { principles of territorial division } \\
\text { into plots }\end{array}$ \\
\hline $\begin{array}{l}\text { Conciliation } \\
\text { procedures }\end{array}$ & $\begin{array}{l}\text { Institutions with neighbouring } \\
\text { municipalities and society }\end{array}$ & $\begin{array}{l}\text { Municipal Spatial Planning } \\
\text { Commission. Checked whether they } \\
\text { comply with planning standards and } \\
\text { requirements for the law; society }\end{array}$ & $\begin{array}{l}\text { Regional Head, the Municipal } \\
\text { Board, neighbouring } \\
\text { municipalities, sector } \\
\text { administrators }\end{array}$ \\
\hline Legal affects & $\begin{array}{l}\text { Legally restricting all; } \\
\text { legal basis for construction } \\
\text { projects and submitting permits } \\
\text { for constructions }\end{array}$ & $\begin{array}{l}\text { Legally restricting; } \\
\text { sets out basic requirements for } \\
\text { building land plots }\end{array}$ & $\begin{array}{l}\text { Legally restricting local } \\
\text { authorities and third parties; } \\
\text { Forms the basis for decisions } \\
\text { regarding conditions for } \\
\text { construction and land use } \\
\text { (planning permission) }\end{array}$ \\
\hline $\begin{array}{l}\text { Compensation for } \\
\text { damage suffered }\end{array}$ & $\begin{array}{l}\text { Mostly banning or changing the } \\
\text { authorized usage by a number of } \\
\text { other special requirements }\end{array}$ & $\begin{array}{l}\text { Compensated for property owners } \\
\text { when land is seized for public } \\
\text { purposes under the simplified } \\
\text { procedure and clear methods of } \\
\text { compensation }\end{array}$ & $\begin{array}{l}\text { If real estate impaired and the } \\
\text { owner wants to sell it }\end{array}$ \\
\hline $\begin{array}{l}\text { Report on } \\
\text { implementation }\end{array}$ & None & Monitoring & $\begin{array}{l}\text { In four cases strictly set by the } \\
\text { law }\end{array}$ \\
\hline $\begin{array}{l}\text { Changes in the } \\
\text { plan }\end{array}$ & $\begin{array}{l}\text { By a simplified procedure } \\
\text { supposing that changes do not } \\
\text { affect the basic principles of the } \\
\text { plan }\end{array}$ & $\begin{array}{l}\text { By simplified procedures when } \\
\text { changes do not affect solutions to } \\
\text { the basic plan }\end{array}$ & New plan \\
\hline $\begin{array}{l}\text { Conditions } \\
\text { necessary for } \\
\text { approval }\end{array}$ & $\begin{array}{l}\text { In special cases, the approval of } \\
\text { higher administrative management }\end{array}$ & $\begin{array}{l}\text { The approval of supervision bodies } \\
\text { of National Spatial Planning }\end{array}$ & Approval is not required \\
\hline Planned territory & Part of Municipality area & $\begin{array}{l}\text { Area of cities, towns, villages or } \\
\text { their parts, blocks }\end{array}$ & $\begin{array}{l}\text { Area (part of it) of the } \\
\text { community }\end{array}$ \\
\hline
\end{tabular}

the conceptual structure, the rights and responsibilities of the participants of the spatial planning process are proposed (see Table 3).

\section{Evaluating the efficiency of the conceptual model}

Harmonious development can be considered as a principle that drives all developmental processes but does not act as an additional requirement for planning. The system for spatial planning documents must be clear and does not allow any potential conflicts concerning the appearance of separate spatial planning documents. The spatial planning information system, to collect and interconnect documents and solutions to strategic and spatial planning at different levels, must be developed to solve this problem.
Such rules could ensure the complexity of spatial planning documents and carry out monitoring and control over the implementation of solutions. The authors evaluated the efficiency of the conceptual model (Table 3).

The achieved results, according to the new conceptual model, are shown in Figure 2. It turns to be clear that the introduction of the new conceptual model for spatial planning in Lithuania will be organized more efficiently. It can be assumed that time for preparing spatial planning documents will decrease.

\section{Conclusions}

The identification of principal investment risks, while analyzing the example of Vilnius district, has disclosed that investment, spatial planning and construction are in- 


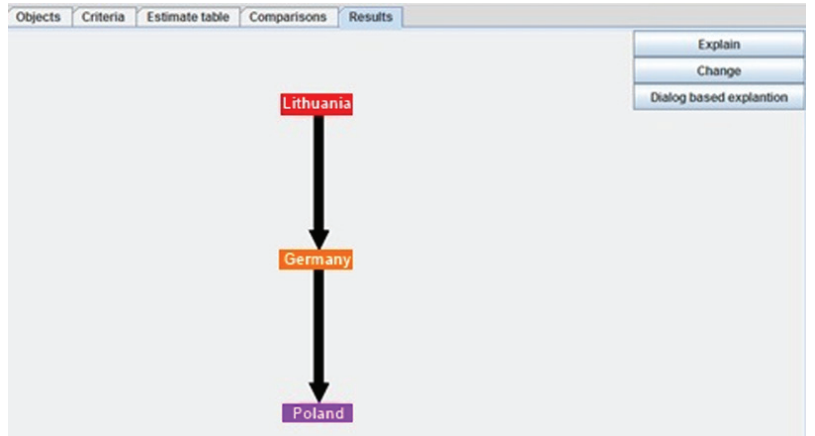

Fig. 2. Comparative results of alternative assessment

terrelated processes and affect each other. Therefore, for assessing the environment of construction investment, it is necessary to assess the complexity and terms of preparing spatial planning documents and related investment risk. Time for preparing spatial planning documents unacceptably increase the risk of investment.

It has been found that:

- the existing spatial planning system is confusing and ineffective because infrastructure (engineering and social) development is not regulated and does not establish legal tools for promoting investment, thereby failing to ensure sustainable development;

- the content and procedures for solutions impact assessment (SIA) of spatial planning documents, the impact assessment of public health, environmental impact assessment (EIA) are formal and duplicate each other. Spatial planning documents do not ensure environmentally friendly solutions, preparation lasts unpredictably and requires additional resources;

- time for preparing spatial planning documents unacceptably increases the risk of investment.

The article includes constraints on infrastructure development in residential areas and proposals to exclude them. The new conceptual model for spatial planning has been presented by the authors.

The evaluation of the conceptual efficiency of the model has been performed. The carried out analysis has showed that spatial planning in Lithuania using the new model will be organized efficiently and time for preparing spatial planning documents will decrease.

\section{References}

Abdul-Rahman, H.; Wang, C.; Lee, Y. L. 2013. Design and pilot run of fuzzy synthetic model (FSM) for risk evaluation in civil engineering, Journal of Civil Engineering and Management 19(2): 217-238. http://dx.doi.org/10.3846/13923730.2012.743926

Abednego, M. P.; Ogunlana, S. O. 2006. Good project governance for proper risk allocation in public-private partnerships in Indonesia, International Journal of Project Management 24(7): 622-634. http://dx.doi.org/10.1016/j.ijproman.2006.07.010

Adams, F. K. 2008. Risk perception and Bayesian analysis of international construction contract risks: the case of payment delays in a developing economy, International Journal of Project Management 26(2): 138-148. http://dx.doi.org/10.1016/j.ijproman.2007.05.007
Al-Azemi, K. F.; Bhamra, R.; Salman, A. F. M. 2014. Risk management framework for build, operate and transfer (BOT) projects in Kuwait, Journal of Civil Engineering and Management 20(3): 415-433. http://dx.doi.org/10.3846/13923730.2013.802706

Alfasi, N.; Almagor, J.; Benenson, I. 2012. The actual impact of the comprehensive lan-use plans: insights from high resolution observations, Land Use Policy 29(4): 862-877. http://dx.doi.org/10.1016/j.landusepol.2012.01.003

Andi. 2006. The importance and allocation of risks in Indonesian construction projects, Construction Management and Economics 24(1): 69-80.

Ashikhmin, I. V.; Furems, E. M.; Larichev, O. I.; Roizenson, G. V. 2003. Decision support system UniComBOS to discreet Multi-criteria choice problems, in DSS in the Uncertainty of the Internet Age. The Karol Adamiecki University of Economics in Katowice, Poland, 111-121.

Banaitienè, N.; Banaitis, A.; Norkus, A. 2011. Risk management in projects: peculiarities of Lithuanian construction companies, International Journal of Strategic Property Management 15(1): 60-73. http://dx.doi.org/10.3846/1648715X.2011.568675

Bank of Lithuania. 2013. Lietuvos ekonomikos raida ir perspektyvos [Lithuanian Economic Outlook] [online], [cited 10 May 2015]. Available from Internet:

http://www.lb.lt/makroekonomines_prognozes (in Lithuanian).

Barber, R. B. 2005. Understanding internally generated risks in projects, International Journal of Project Management 23(8): 584-590.

http://dx.doi.org/10.1016/j.ijproman.2005.05.006

Bass, S.; Dalal-Clayton, B.; Pretty, J. 1995. Participation in strategies for sustainable development. Environmental planning issues, No 7. International Institute for Environment and Development, London, UK. 117 p.

Bing, L.; Akintoye, A.; Edwards, P. J.; Hardcastle, C. 2005. The allocation of risk in PPP/PFI construction projects in the UK, International Journal of Project Management 23(1): 25-35. http://dx.doi.org/10.1016/j.ijproman.2004.04.006

Campbell, H.; Marshall, R. 2002. Utilitarianism's bad breath? A re-evaluation of the public interest justification for planning, Planning Theory 1: 163-187. http://dx.doi.org/10.1177/147309520200100205

Charoenngam, C.; Yeh, C. Y. 1999. Contractual risk and liability sharing in hydropower construction, International Journal of Project Management 17(1): 29-37. http://dx.doi.org/10.1016/S0263-7863(97)00064-1

Chen, Z.; Li, H.; Ren, H.; Xu, Q.; Hong, J. 2011. A total environmental risk assessment model for international hub airports, International Journal of Project Management 29(7): 856-866.

http://dx.doi.org/10.1016/j.ijproman.2011.03.004

Doloi, H. 2012. Understanding impacts of time and cost related construction risks on operational performance of PPP projects, International Journal of Strategic Property Management 16(3): 316-337.

http://dx.doi.org/10.3846/1648715X.2012.688774

El-Sayegh, S. M. 2007. Risk assessment and allocation in the UAE construction industry, International Journal of Project Management 26(4): 431-438.

http://dx.doi.org/10.1016/j.ijproman.2007.07.004

Faludi, A. 1973. Planning theory. Oxford: Pergamon press. 306 p.

Furems, E. M.; Gnedenko, L. S. 1992. Interactive procedure for non-transitivity revealing and correcting under pairwise comparisons, Information Systems and Operations Research 4(1): 118-126.

Hassanein, A. A. G.; Afify, H. M. F. 2007. A risk identification procedure for construction contracts - a case study 
of power station projects in Egypt, Civil Engineering and Environmental Systems 24(1): 3-14.

http://dx.doi.org/10.1080/10286600600910104

Jin, F.; Liu, P.; Zhang, X. 2013. The multi-attribute group decision making method based on the interval grey linguistic variables weighted harmonic aggregation operators, Technological and Economic Development of Economy 19(3): 409-430. http://dx.doi.org/10.3846/20294913.2013.821685

Jun, L.; Qiuzhen, W.; Qingguo, M. 2011. The effects of project uncertainty and risk management on IS development project performance: a vendor perspective, International Journal of Project Management 29(7): 923-933. http://dx.doi.org/10.1016/j.ijproman.2010.11.002

Kartam, N. A.; Kartam, S. A. 2001. Risk and its management in the Kuwaiti construction industry: a contractors' perspective, International Journal of Project Management 19(6): 325-335. http://dx.doi.org/10.1016/S0263-7863(00)00014-4

Ke, Y.; Wang, S. Q.; Chan, A. P. C. 2012. Risk management practice in China's Public-Private Partnership projects, Journal of Civil Engineering and Management 18(5): 675-684. http://dx.doi.org/10.3846/13923730.2012.723380

Ke, Y.; Wang, S. Q.; Chan, A. P. C.; Lam, P. T. I. 2010. Preferred risk allocation in China's public-private partnership (PPP) projects, International Journal of Project Management 28(5): 482-492. http://dx.doi.org/10.1016/j.ijproman.2009.08.007

Khattab, A. A.; Anchor, J.; Davies, E. 2007. Managerial perceptions of political risk in international projects, International Journal of Project Management 25(7): 734-743. http://dx.doi.org/10.1016/j.ijproman.2007.03.006

Komarovska, A. 2013. Teritoriju planavimo proceso daugiatikslis vertinimas investiciniu aspektu [Multiple criteria assessment of spatial planning process in context of investment]: PhD Thesis. Vilnius: Technika. 151 p. (in Lithuanian).

Korhonen, P.; Larichev, O. I.; Moshkovich, H.; Mechitov, A.; Wallenius, J. 1997. Choice behavior in a computer-aided multiattribute decision task, Journal of Multicriteria Decision Analysis 6: 233-246.

http://dx.doi.org/10.1002/(SICI)1099-1360(199707)6: 4<233::AID-MCDA156>3.0.CO;2-S

Kutsch, E.; Hall, M. 2010. Deliberate ignorance in project risk management, International Journal of Project Management 28(3): 245-255.

http://dx.doi.org/10.1016/j.ijproman.2009.05.003

Lam, K. C.; Wang, D.; Lee, P. T. K.; Tsang, Y. T. 2007. Modelling risk allocation decision in construction contracts, International Journal of Project Management 25(5): 485493. http://dx.doi.org/10.1016/j.ijproman.2006.11.005

Larichev, O. I. 1992. Cognitive validity in design of decisionaiding techniques, Journal of Multi-criteria Decision Analysis 1(3): 127-138.

http://dx.doi.org/10.1002/mcda.4020010303

Larichev, O.; Moshkovich, H. M. 1997. Verbal decision analysis for unstructured problems. Boston: Kluwer Academic Press. $260 \mathrm{p}$.

Larichev, O.; Moshkovich, E. 1996. Kachestvennye metody prinjatija reshenij [Larichev, O.; Moshkovich, E. Qualitative decision making methods]. Moskva: Fizmat (in Russian).

Lietuvos Respublikos pridètinès vertès mokesčio istatymas [Value Added Tax Law] (Žin., 2002, Nr. 35-1271) (in Lithuanian).

Lietuvos Respublikos statybos istatymas [Construction Law] (Žin., 1996, Nr. 32-788) (in Lithuanian).

Lietuvos Respublikos teritoriju planavimo istatymas [Spatial Planning Law] (Žin., 1995, Nr. 107-2391).
Moore, T. 1978. Why allow planners to do what they do? A justification from economic theory, Journal of the American Planning Association 44(4): 387-398. http://dx.doi.org/10.1080/01944367808976917

$\mathrm{Ng}$, A.; Loosemore, M. 2007. Risk allocation in the private provision of public infrastructure, International Journal of Project Management 25(1): 66-76. http://dx.doi.org/10.1016/j.ijproman.2006.06.005

Nieto-Morote, A.; Ruz-Vila, F. 2011. A fuzzy approach to construction project risk assessment, International Journal of Project Management 29(2): 220-231. http://dx.doi.org/10.1016/j.ijproman.2010.02.002

Perminova, O.; Gustafsson, M.; Wikström, K. 2008. Defining uncertainty in projects - a new perspective, International Journal of Project Management 26(1): 73-79. http://dx.doi.org/10.1016/j.ijproman.2007.08.005

Reed, A. H.; Knight, L. V. 2010. Effect of a virtual project team environment on communication-related project risk, International Journal of Project Management 28(5): 422-427. http://dx.doi.org/10.1016/j.ijproman.2009.08.002

Rohaninejad, M.; Bagherpour, M. 2013. Application of risk analysis within value management: a case study in dam engineering, Journal of Civil Engineering and Management 19(3): 364-374. http://dx.doi.org/10.3846/13923730.2012.744770

Sanderson, J. 2012. Risk, uncertainty and governance in megaprojects: a critical discussion of alternative explanations, International Journal of Project Management 30(4): 432-443. http://dx.doi.org/10.1016/j.ijproman.2011.11.002

Schieg, M. 2006. Risk management in construction project management, Journal of Business Economics and Management 7(2): 77-83.

Simanavičienè, R.; Liaudanskiene, R.; Ustinovichius, L. 2012a. A new synthesis method of structural, technological and safety decisions (SyMAD-3), Journal of Civil Engineering and Management 18(2): 265-276.

http://dx.doi.org/10.3846/13923730.2012.666504

Simanavičienè, Ž.; Keizerienè, E.; Žalgiryte, L. 2012b. Lietuvos nekilnojamojo turto rinka: nekilnojamojo turto ir statybos sąnaudų kainų analizè, Economics and Management 17(3): 1034-1041 (in Lithuanian).

http://dx.doi.org/10.5755/j01.em.17.3.2115

Šostak, O. R.; Makutėnienè, D. 2013a. Timely determining and preventing conflict situations between investors and third parties: some observations from Lithuania, International Journal of Strategic Property Management 17(4): 390404. http://dx.doi.org/10.3846/1648715X.2013.863239

Šostak, O. R.; Makutėniené, D. 2013b. Modelling a dispute hearing between an investor and the public concerned in administrative courts of the Republic of Lithuania, Technological and Economic Development of Economy 19(3): 489-509. http://dx.doi.org/10.3846/20294913.2013.817489

The Concept of the new Version of the Law on Territorial Planning. 2010. Lietuvos Respublikos Vyriausybès 2010-03-31 nutarimas Nr. 422 dèl naujos redakcijos Lietuvos Respublikos teritoriju planavimo istatymo koncepcijos (Źin., 2010, Nr. 47-2248).

The Investment Promotion Program. 2008. Lietuvos Respublikos Vyriausybès 2007-12-19 nutarimas Nr. 1447 dèl investicijų skatinimo 2008-2013 metų programos patvirtinimo (Žin., 2008, Nr. 7-239) (in Lithuanian).

Ustinovichius, L. 2004. Determination of efficiency of investments in construction, International Journal of Strategic Property Management 8(1): 25-44.

Ustinovichius, L. 2007. Methods of determining objective, subjective and integrated weights of attributes, International Journal of Management and Decision Making 8(5/6): 540-554. http://dx.doi.org/10.1504/IJMDM.2007.013417 
Ustinovichius, L.; Barvidas, A.; Vishnevskaja, A.; Ashikhmin, I. V. 2011. Multicriteria verbal analysis of territory planning system's models from legislative perspective, Journal of Civil Engineering and Management 17(1): 16-26. http://dx.doi.org/10.3846/13923730.2011.554173

Wang, J.; Yuan, H. 2011. Factors affecting contractors' risk attitudes in construction projects: case study from China, International Journal of Project Management 29(2): 209219. http://dx.doi.org/10.1016/j.ijproman.2010.02.006

Wei, G.; Zhao, X. 2014. Methods for probabilistic decision making with linguistic information, Technological and Economic Development of Economy 20(2): 193-209. http://dx.doi.org/10.3846/20294913.2014.869515

Wibowo, A.; Mohamed, S. 2010. Risk criticality and allocation in privatised water supply projects in Indonesia, International Journal of Project Management 28(5): 504-513. http://dx.doi.org/10.1016/j.ijproman.2009.08.003

Xu, Y.; Lu, Y.; Chan, A. P. C.; Skibniewski, M. J.; Yeung, J. F. Y. 2012. A computerized risk evaluation model for publicprivate partnership (PPP) projects and its application, International Journal of Strategic Property Management 16(3): 277-297.

http://dx.doi.org/10.3846/1648715X.2012.686928
Zavadskas, E. K.; Turskis, Z.; Tamošaitienè, J. 2010. Risk assessment of construction projects, Journal of Civil Engineering and Management 16(1): 33-46. http://dx.doi.org/10.3846/jcem.2010.03

Zayed, T.; Amer, M.; Pan, J. 2008. Assessing risk and uncertainty inherent in Chinese highway projects using AHP, International Journal of Project Management 26(4): 408-419. http://dx.doi.org/10.1016/j.ijproman.2007.05.012

Zhang, H. 2007. A redefinition of the project risk process: Using vulnerability to open up the event-consequence link, International Journal of Project Management 25(7): 694-701. http://dx.doi.org/10.1016/j.ijproman.2007.02.004

Zhang, N. 2013. Method for aggregating correlated interval grey linguistic variables and its application to decision making, Technological and Economic Development of Economy 19(2): 189-202. http://dx.doi.org/10.3846/20294913.2012.763071

Zou, P. X. W.; Li, J. 2010. Risk identification and assessment in subway projects: case study of Nanjing Subway Line 2, Construction Management and Economics 28(12): 12191238. http://dx.doi.org/10.1080/01446193.2010.519781

Zou, P. X. W.; Zhang, G.; Wang, J. 2007. Understanding the key risks in construction projects in China, International Journal of Project Management 25(6): 601-614. http://dx.doi.org/10.1016/j.ijproman.2007.03.001

Andželika KOMAROVSKA. Dr. from Vilnius Gediminas Technical University (2013). Research interests: risk management, decision-making theory, automation in design, expert systems.

Leonas USTINOVICHIUS. Dr Habil Prof, Chairman of the Laboratory of Construction Technology and Management at Vilnius Gediminas Technical University. Doctor (1989), Doctor Habil (2002). Published more than 150 scientific papers. Research interests: building technology and management, decision-making theory, automation in design, expert systems.

Aurelija PECKIENĖ. PhD student at the Department of Construction Technology and Management, Vilnius Gediminas Technical University. Research interests: risk management, decision-making theory, automation in design. 